Jurnal Teknologi Pendidikan, Vol. 14, No. 1, April 2021, e-ISSN: 2407-7437

\title{
ASESMEN PENGGUNAAN MULTIMEDIA PEMBELAJARAN INTERAKTIF BIOLOGI OLEH SISWA SEBAGAI KLASIFIKASI TINGKAT DIGITAL LITERACY PENDUKUNG PROGRAM MERDEKA BELAJAR DI ACEH BARAT
}

\author{
Rita Oktavia ${ }^{1}$, Rufa Hera ${ }^{1}$, Mardhatillah $^{1}$, Nur Rokhman ${ }^{2}$ \\ ${ }^{1}$ STKIP Bina Bangsa Meulaboh, ${ }^{2}$ Universitas Dian Nuswantoro \\ ${ }^{1}$ ritaoktavia87@gmail.com, ${ }^{2}$ nurrokhman@dsn.dinus.ac.id
}

\begin{abstract}
Abstrak: Penelitian ini bertujuan untuk membuktikan hasil asesmen penggunaan multimedia pembelajaran interaktif Biologi oleh siswa sebagai identifikasi tingkat digital literasi pendukung program merdeka belajar di Aceh Barat. Penelitian dilakukan di dua SMA Negeri Kabupaten Aceh Barat. Penelitian dilaksanakan pada semester ganjil tahun 2020. Sampel penelitian di ambil dari kelas XII MIA dari masing-masing sekolah yaitu SMA N 1 Meureubo berjumlah 30 siswa dan MAN 2 Aceh Barat berjumlah 30 siswa. Teknik pengumpulan data yang digunakan adalah angket dan dokumentasi. Teknik analisa data menggunakan statistika deskriptif dengan tahapan Penilaian Acuan Patokan (PAP Tipe II). Berdasarkan hasis asesmen dibuktikan bahwa tingkat literasi digital siswa masuk penilaian kategori Tinggi pada MAN 2 Aceh Barat. Sedangkan Pada SMA N 1 Meureubo kategori penilaian tingkat literasi digital siswa Rendah. Membuktikan bahwa penggunaan akses Multimedia interaktif disekolah di SMA Aceh Barat belum merata digunakan oleh siswa. Penerapan multimedia interaktif oleh guru belum diterapkan secara maksimal, artinya pengetahuan dan keahlian digital literasi guru SMA Aceh Barat belum termediasi dan terfasilitasi dengan baik.
\end{abstract}

Kata Kunci: Tingkat Digital Literasi, Multimedia, Multimedia Interaktif

\begin{abstract}
This study aims to prove the results of the assessment of the use of interactive multimedia learning Biology by students as identification of the digital literacy level to support the independent learning program in West Aceh.The research was conducted in two State Senior High Schools of West Aceh Regency. The research was conducted in the odd semester of 2020. The research sample was taken from class XII MIA from each school, namely SMA N 1 Meureubo totaling 30 students and MAN 2 Aceh Barat totaling 30 students. The research approach uses a quantitative approach.The data collection techniques used were questionnaires and documentation. The data analysis technique used descriptive statistics with the Benchmark Reference Assessment stage (PAP Type II). Based on the results of the assessment, it was proven that the digital literacy level of students was included in the High category assessment at MAN 2 Aceh Barat. Meanwhile, at SMA N 1 Meureubo, the assessment category for students' digital literacy level is Low. It proves that the use of interactive multimedia access in schools in West Aceh High School has not been evenly used by students. The teacher's application of interactive multimedia has not been maximally applied, meaning that the digital literacy knowledge and skills of West Aceh Senior High School teachers have not been mediated and facilitated properly.
\end{abstract}

Keyword: Levels of Digital Literacy, digital literacy, Multimedia, Interactive Multimedia.

\section{PENDAHULUAN}

Pendidikan di Indonesia telah memasuki era digital dimana siap tidak siap kita harus mampu menguasai teknologi yang ada disekitar kita. Selanjutnya, bagaimana langkah yang harus dilakukan oleh guru dan siswa menghadapi era digital yaitu tetap memanfaatkan teknologi yang bisa dijangkau, memaksimalkan pemanfaatan teknologi yang ada, menggunakan aplikasi-aplikasi yang ada di handphone seperti whatsapp, google class room, zoom, google meet, google form, youtube dan lainnya. Artinya, sangat penting saat ini bagi siswa dan guru untuk aktif dalam mengakses teknologi untuk memaksimalkan hasil kompetensi siswa dan guru serta dapat meningkatkan digital literasi di era digital saat ini. Sehingga dapat mencapai tujuan yaitu membentuk generasi emas di era digital dalam program merdeka belajar. Selanjutnya, untuk dapat meningkatkan kompetensi siswa di era digital, telah banyak produk-produk pembelajaran berbasis multimedia interaktif yang dikembangkan dalam berbagai bidang pengetahuan, termasuk dalam pembelajaran biologi.

Di sekolah menengah atas, kompetensi siswa menjadi sangat penting karna bagian dari ujung tombak wajib belajar, sebelum siswa memasuki dunia akademisi. Multimedia pembelajaran interaktif adalah salah satu pilihan yang tepat untuk memenuhi kebutuhan generasi era milenial karena multimedia sendiri berarti penggabungan beberapa media yang mencakup teks, grafik, animasi, audio dan video serta dapat mengembangkan proses belajar ke arah yang lebih dinamis.

Hasil penelitian pada beberapa kasus dalam penerapan multimedia interaktif memperoleh hasil yang positif baik. Hasil 
penelitian menunjukkan terjadi peningkatan motivasi siswa sebelum dan setelah menggunakan multimedia interaktif pada siswa SMA kelas XI (Triyanti, 2015).

Dalam hasil riset lain tentang pengaruh penerapan metode pembelajaran multimedia interaktif berbasis macromedia flash 8 materi sistem saraf manusia terhadap keaktifan dan hasil belajar siswa di SMA PPMI Assalaam Sukoharjo tahun pelajaran 2016/2017 menunjukkan hasil signifikan berpengaruh baik terhadap keaktifan dan hasil belajar (Wulandari, 2017). Dengan Pengembangan model inkuiri terbimbing berbantuan multimedia interaktif terhadap keterampilan berpikir kritis siswa SMA juga menunjukkan hasil bahwa keterampilan berpikir kritis siswa meningkat dengan penerapan inkuiri terbimbing berbantuan multimedia (Retnosari et al., 2016).

Dibeberapa sekolah SMA di Aceh Multimedia pembelajaran interaktif telah diterapkan kepada siswa diantaranya penggunaan multimedia dapat meningkatkan hasil belajar siswa dan minat belajar peserta didik pada materi Sistem Ekskresi Manusia di SMA Negeri 11 Aceh Barat Daya(Dewi, 2021). Hasil riset lain tentang pengaruh multimedia interaktif terhadap keaktifan dan pengetahuan siswa pada materi jaringan tumbuhan dibuktikan bahwa memiliki pengaruh yang signifikan pada siswa kelas XI SMA N 6 Darul Makmur (Oktavia, 2020). Pada hasil pengembangan produk electronic book rata-rata uji coba pada kelompok kecil adalah 96,43\% (kategori sangat baik), kepada kelompok besar memperoleh persentase rata-rata uji coba pemakaian $100 \%$ (kategori sangat baik), sehingga dari nilai persentase tersebut electronic book pada materi hukum dasar kimia layak digunakan di SMAN 1 Panton Reu Aceh Barat(Andani \& Yulian, 2018).

Untuk dapat menerapkan Multimedia pembelajaran interaktif khususnya di Aceh Barat secara maksimal, maka diperlukan asesmen penggunaan Multimedia pembelajaran interaktif oleh sisiwa sehingga dapat mengetahui arah ketertarikan siswa, karakter siswa dan kebutuhan siswa dengan maksimal. Mengapa asesmen ini begitu penting karena sangat erat kaitannya dengan tingkat digital literasi siswa sebagai pengguna media secara langsung dan guru dalam penerapan pembeajaran langsung sebagai upaya mengikuti perkembangan era digital dan program merdeka belajar yang sedang diterapkan secara bertahap oleh pemerintah. Artinya, sebelum menerapkan dengan maksimal Multimedia pembelajaran interaktif sebaiknya dilakukan asesmen penggunaan multimedia pembelajaran interaktif oleh siswa sebagai tolak ukur dalam pengembangan Multimedia pembelajaran interaktif dalam pembelajaran khususnya Biologi. Dari hasil tersebut, maka guru dan sekolah dapat menerapkan kebijakan langkah tepat yang dilakukan, misalnya penerapan Multimedia pembelajaran interaktif (MPI) menggunakan aplikasi tertentu, berbasis penggunaan fasilitas tertentu misal laboratorium komputer, handphone dengan berbasis android,dan dapat mengembangkan Multimedia pembelajaran interaktif dengan fitur yang menarik seperti apa yang diminati siswa. Selain, harus tersedia sarana dan prasarana, kemandirian guru dan siswa, tingkat kemampuan digital literasi guru juga sangat berpengaruh untuk mencapai tujuan merdeka belajar ini.

Selain itu kompetensi literasi digital bisa ditempuh dengan metode pelatihan secara kontinyu, untuk mengatasi permaslahan di era digital. Keahlian dasar menjadi aspek yang harus dimiliki oleh guru dan pelajar. Kompetensi litersi digital tingkat dasar dan tingkat lanjut terangkum dalam sepuluh tahap berikut: mengakses, menyeleksi, memahami, menganalisis, memverifikasi, mengevaluasi, mendistribusikan, memproduksi, berpartisipasi, dan berkolaborasi (Asari et al., 2019). Hasil riset tingkat literasi digital siswa SMA masuk kategori penilaian tingkat literasi digital siswa Rendah pada SMA N 1 Kuala. Dan kategori penilaian tingkat literasi digital siswa Cukup pada SMA N 3 Kuala (Oktavia \& Hardinata, 2020).

Untuk memenuhi data profil tingkat digital literasi siswa SMA di Kabupaten Aceh Barat maka penelitian ini sangat penting dilakukan. Ditargetkan tahapan penelitian yang akan dilakukan adalah memperoleh hasil asesmen penggunaan oleh siswa sehingga menemukan tingkat digital literasi siswa. Selanjutnya, asesmen tingkat digital literasi guru, kemudian melakukan pengembangan MPI dengan cara mudah seperti berbasis power point terintegrasi android, kemudian dapat diterapkan dalam pembelajaran di sekolah SMA di Aceh Barat.

Manfaat khusus penelitian adalah untuk memperoleh hasil penilaian asesmen terhadap penggunaan $\mathrm{mPI}$ oleh siswa dalam pembelajaran 
biologi di sma, pada tiga sekolah di aceh barat sebagai gambaran awal data tingkat literasi siswa.

Tujuan penelitian adalah untuk membuktikan hasil asesmen penggunaan multimedia pembelajaran interaktif Biologi oleh siswa sebagai identifikasi tingkat digital literasi pendukung program merdeka belajar di Aceh Barat.

\section{METODE PENELITIAN}

Pendekatan penelitian menggunakan pendekatan kuantitatif. Penelitian ini bersifat expost facto. Hal ini disebabkan dalam penelitian tidak dibuat perlakuan atau manipulasi terhadap variabel penelitian, melainkan hanya gejala yang telah terjadi pada diri responden sebelum penelitian ini dilakukan.

Penelitian dilakukan di dua SMA Negeri Kabupaten Aceh Barat. Penelitian dilaksanakan pada semester ganjil tahun 2020. Subjek dalam penelitian ini adalah siswa-siswi SMA Negeri Kabupaten Aceh Barat.

Objek penelitian adalah tingkat literasi digital siswa ditinjau dari penggunaan dan pemanfaatan Multimedia pembelajaran Interaktif dan Teknologi Informasi sebagai mobile learning dalam pembelajaran Biologi.

Populasi dalam penelitian ini terdiri dari siswa kelas XII yang berasal dari dua sekolah SMA di kabupaten Aceh Barat. Sampel penelitian di ambil dari kelas XII MIA dari masing-masing sekolah yaitu SMA $\mathrm{N} \quad 1$ Meureubo berjumlah 30 siswa dan MAN 2 Aceh Barat berjumlah 30 siswa. Dengan total keseluruhan siswa 60 siswa. Sampel ditentukan dengan menggunakan teknik Purposive Sampling. Dengan pertimbangan bahwa kelas XII sudah melakukan kegiatan literasi digital untuk proses belajar dikelas maupun diluar kelas.

Teknik pengumpulan data yang digunakan adalah angket dan dokumentasi. Teknik analisa data menggunakan statistika deskriptif dengan tahapan Penilaian Acuan Patokan (PAP)(Alfath \& Raharjo, 2019) (Sidin \& Khaeruddin, 2012). Tahapan penilaian mengikuti modifikasi metode (Feliska, 2019). Penyajian data dibuat dalam bentuk tabel nilainilai statistiknya, sedangkan patokan penilaian menggunakan Penilaian Acuan Patokan atau PAP Tipe II dengan nilai presentil sebagai berikut:
Tabel 1 Nilai Persetil PAP Tipe II

\begin{tabular}{ll}
\hline Nilai Persentil & Kategori \\
\hline $81 \%-100 \%$ & Sangat Tinggi \\
$66 \%-80 \%$ & Tinggi \\
$56-65 \%$ & Cukup \\
$46-55 \%$ & Rendah \\
$0-45 \%$ & Sangat Rendah \\
\hline
\end{tabular}

Pada tingkat literasi digital peneliti menetapkan skor terendah 1 dan skor tertinggi 5 untuk pengukuran tingkat literasi digital. Langkah pertama yang harus dilakukan adalah menentukan interval skor dengan modifikasi rumus PAP Tipe II sebagai berikut:

$$
N T R+(\text { nilai persentilx }(N T T-N T R))
$$

Keterangan:

NTT: Nilai tertinggi yang mungkin terjadi

NTR: Nilai terendah yang mungkin terjadi

Perhitungan rentang skor untuk variabel tingkat literasi digital siswa yang diukur dengan 30 item pertanyaan berdasarkan PAP Tipe II adalah sebagai berikut:

Skor tertinggi: 5 x $30=150$

Skor terendah: 1 × $30=30$

Rentang skor untuk variabel tingkat literasi digital sebagai berikut:

Tabel 2 Interval Skor Tingkat Literasi Digital Siswa berdasarkan PAP Tipe II:

\begin{tabular}{ccc}
\hline \multicolumn{1}{c}{ Perhitungan } & $\begin{array}{c}\text { Rentang } \\
\text { skor }\end{array}$ & $\begin{array}{c}\text { Kategori } \\
\text { penilaian }\end{array}$ \\
\hline $30+81 \%(150-30)$ & $127-150$ & Sangat tinggi \\
$30+66 \%(150-30)$ & $109-<126$ & Tinggi \\
$30+56 \%(150-30)$ & $97-<108$ & Cukup \\
$30+46 \%(150-30)$ & $85-<96$ & Rendah \\
$30+0 \%(150-30)$ & $30-<84$ & Sangat rendah \\
\hline
\end{tabular}

\section{HASIL DAN PEMBAHASAN}

Untuk membuktikan hasil asesmen penggunaan multimedia pembelajaran interaktif Biologi oleh siswa sebagai identifikasi tingkat digital literasi pendukung program merdeka belajar di Aceh Barat dijabarkan dari interval Tingkat digital literasi tersebut. Dengan menghitung persentase dari masing-masing frekuensi dari rentang skor yang ditentukan (Tabel 3).

Interpretasi data tingkat digital siswa SMA pada pembelajaran Biologi disajikan pada tabel berikut: 
Tabel 3 Kategori penilaian Tingkat Literasi Digital siswa MAN 2 Aceh Barat berdasarkan PAP Tipe II

\begin{tabular}{cccc}
\hline $\begin{array}{c}\text { Rentang } \\
\text { skor }\end{array}$ & $\mathrm{f}$ & $\%$ & $\begin{array}{c}\text { Kategori } \\
\text { penilaian }\end{array}$ \\
\hline $127-150$ & 0 & 0 & Sangat tinggi \\
$109-<126$ & 10 & 33.3 & Tinggi \\
$97-<108$ & 9 & 30 & Cukup \\
$85-<96$ & 6 & 20 & Rendah \\
$30-<84$ & 5 & 16.7 & Sangat rendah \\
Jumlah & 30 & $100 \%$ & \\
\hline
\end{tabular}

Tabel 4 Kategori penilaian Tingkat Literasi Digital siswa SMA Negeri 1 Meureubo berdasarkan PAP Tipe II

\begin{tabular}{cccc}
\hline $\begin{array}{c}\text { Rentang } \\
\text { skor }\end{array}$ & $\mathrm{f}$ & $\%$ & $\begin{array}{c}\text { Kategori } \\
\text { penilaian }\end{array}$ \\
\hline $127-150$ & & & Sangat tinggi \\
$109-<126$ & 9 & 30 & Tinggi \\
$97-<108$ & 8 & 26.7 & Cukup \\
$85-<96$ & 10 & 33.3 & Rendah \\
$30-<84$ & 3 & 10 & Sangat rendah \\
Jumlah & 30 & $100 \%$ & \\
\hline
\end{tabular}

Dari hasil tersebut dapat diketahui pada Man 2 Aceh Barat tingkat digital literasi siswa berdasarkan PAP Tipe II masuk kategori penilaian tinggi dengan persentase 33,3\%. Sedangkan pada SMA N 1 Meureubo tingkat digital literasi siswa masuk kategori penilaian Rendah dengan persentase 33,3\%. Dapat diketahui bahwa kategori penilaian tingkat literasi digital siswa Tinggi pada MAN 2 Aceh Barat. Sedangkan pada SMA N 1 Meureubo kategori penilaian tingkat literasi digital siswa Rendah.

Ditinjau dari soal angket terkait digital literasi dalam pembelajaran Biologi yang diberikan dapat dianalisis beberapa soal yang memiliki skoring persentase rendah pada MAN 2 Aceh Barat yaitu pada pernyataan nomor 5,14,21, dan 29 dengan pernyataan sebagai berikut: Saya sering mengakses buku-buku Biologi gratis di internet, saya menggunakan akun medsos untuk berbagi informasi Biologi, ketika waktu senggang, saya mengakses internet untuk membaca materi Biologi, dan saya mendowload vidio tentang pelajaran biologi disekolah. Sementara pada SMA N 1 Meureubo memperoleh skoring persentase rendah Meureubo selain soal no 5, juga soal no 4 yaitu biasanya saya mencari informasi terkait Biologi berupa teks. Dan skoring persentase sangan rendah pada soal 16 dan 17 yaitu guru menjelaskan materi biologi menjelaskan materi biologi menggunakan media komputer, dan apakah guru biologi anda menampilkan anaimasi dan gambar pada penyampaian materi?. Jika dianalisis pada kedua SMA Aceh Barat tersebut siswa MAN 2 Aceh Barat memiliki pengetahuan literasi digital yang baik, dan tingkat digital literasi yang tinggi.

Namun pada beberapa komponen seperti frekuensi mengakses buku-buku Biologi gratis di internet, menggunakan akun medsos untuk berbagi informasi Biologi, mengakses internet untuk membaca materi Biologi, dan mendowload vidio tentang pelajaran biologi disekolah ini masih rendah dilakukan oleh siswa.

Selanjutnya pada siswa SMA N 1 Meureubo, siswa masih belum memiliki pengetahuan literasi digital yang baik, dan tingkat literasi digital yang Rendah. Berdasarkan komponen pernyataan dapat diketahui bahwa frekuensi siswa mencari informasi terkait Biologi berupa teks rendah. Artinya minat siswa menunjukkan kearah multimedia yang lain seperti vidio, audio, animasi dan gambar. Juga dapat dianalisis bahwa penerapan multimedia interaktif oleh guru belum di terapkan. Dibuktikan dengan skoring persentase rendah pada komponen guru menjelaskan materi biologi menggunakan media komputer, dan guru biologi menampilkan animasi dan gambar pada penyampaian materi Biologi.

Dari hasil yang ditemukan membuktikan bahwa penggunaan Multimedia interaktif disekolah belum merata diterapkan di SMA Aceh Barat. Selain keahlian dasar yang dimiliki tenaga pendidik yang belum termediasi dan terfasilitasi, ini juga membuktikan adanya pergerakan penerapan multimedia yang belum merata di sekolah Menengah atas. Kemandirian siswa diawali dengan kemandirian guru. Jika guru tidak memiliki pengetahuan digital literasi yang baik maka demikian dengan siswa sebagai pengkonsumsi langsung multimedia.

Selain itu, penerapan literasi digital dapat didorong dengan memaksimalkan pemanfaatkan handphone dengan memberikan link media pembelajaran dan vidio-vidio yang di share ke grup. Guru dapat memberikan tugas dirumah dengan mendorng siswa untuk mengakses media pembelajaran dengan pendampingan. Dengan penggunaan media-media digital juga secara langsung meningkatkan digital literasi siswa. 
Pada beberapa hasil kajian penerapan Multimedia pembelajaran interaktif telah banyak membuktikan bahwa siswa memperoleh hasil belajar yang lebih baik. Hasil penelitian terkait menunjukkan terjadinya peningkatan motivasi siswa setelah menggunakan multimedia interaktif serta peningkatan hasil belajar siswa setelah menggunakan multimedia interaktif dengan kategori sedang(Triyanti, 2015).

\section{PENUTUP}

Berdasarkan hasil asesmen penggunaan multimedia pembelajaran interaktif biologi oleh siswa sebagai identifikasi tingkat digital literacy pendukung program merdeka belajar di Aceh Barat dibuktikan bahwa tingkat literasi digital siswa masuk penilaian kategori Tinggi pada MAN 2 Aceh Barat. Sedangkan Pada SMA N 1 Meureubo kategori penilaian tingkat literasi digital siswa Rendah. Membuktikan bahwa penggunaan akses Multimedia interaktif disekolah di SMA Aceh Barat belum merata diterapkan oleh siswa dan guru. Penerapan multimedia interaktif oleh guru belum diterapkan secara maksimal, artinya pengetahuan dan keahlian digital literasi guru SMA Aceh Barat belum termediasi dan terfasilitasi dengan baik.

Bagi peneliti untuk melakukan asesmen ke beberapa sekolah lainnya di Aceh Barat untuk melengkapi data profil tingkat digital literasi siswa dengan penerapan akses multimedia dalam pembelajaran Biologi. Selanjutnya mengkaji tingkat digital literasi guru SMA, kemudian melakukan pengembangan Multimedia pembelajaran interaktif dengan cara bertahap, dan mudah diduplikasi dan diaplikasikan seperti pengembangan multimedia intrekatif berbasis power point terintegrasi android, sehingga dapat diterapkan dalam pembelajaran Biologi di SMA Aceh Barat.

\section{DAFTAR PUSTAKA}

Alfath, K., \& Raharjo, F. F. (2019). Teknik Pengolahan Hasil Asesmen: Teknik Pengolahan Dengan Menggunakan Pendekatan Acuan Norma (PAN) dan Pendekatan Acuan Patokan (PAP). Jurnal Komunikasi Dan Pendidikan Islam, Vol. 8(No. 1), 1-28. file://C:/Users/ACER/Downloads/105190-1-SM.pdf

Andani, D. T., \& Yulian, M. (2018). Pengembangan Bahan Ajar Electronic
Book Menggunakan Software Kvisoft Flipbook Pada Materi Hukum Dasar Kimia di SMA Negeri 1 Panton Reu Aceh Barat. Jurnal IPA \& Pembelajaran IPA, 2(1), $1-6$. https://doi.org/10.24815/jipi.v2i1.10730

Asari, A., Kurniawan, T., Ansor, S., Bagus, A., \& Rahma, N. (2019). Kompetensi Literasi Digital Bagi Guru Dan Pelajar Di. BIBLIOTIKA: Jurnal Kajian Perpustakaan Dan Informasi, 3, 98-104.

Dewi, R. (2021). Penggunaan Multimedia Terhadap Minat Dan Hasil Belajar Peserta Didik Pada Materi Sistem Ekresi Manusia Di SMA N 11 Aceh Barat Daya.

Feliska, H. . (2019). Tingkat Literasi Digital Siswa ditinjau dari Prestasi Belajar, Jenis Kelamin, Dan Motivasi Belajar. Duke Law Journal, 1(1), 1-13. https://doi.org/10.1017/CBO9781107415 324.004

Oktavia, R. (2020). Pengaruh Multimedia Interaktif pada pembelajaran Biologi Jaringan Tumbuhan Terhadap Keaktifan Dan Pengetahuan Siswa SMAN 6 Darul Makmur. Edunesia: Jurnal Ilmiah Pendidikan, 1(3), 73-81.

Oktavia, R., \& Hardinata, A. (2020). TINGKAT LITERASI DIGITAL SISWA DITINJAU DARI PENGGUNAAN TEKNOLOGI INFORMASI SEBAGAI MOBILE LEARNING DALAM PEMBELAJARAN BIOLOGI PADA SISWA MENGENGAH ATAS ( SMA ) KECAMATAN KUALA NAGAN RAYA. Bionatural, VII(2), 26-34.

Retnosari, N., Susilo, H., \& Suwono, H. (2016). Pengaruh Model Pembelajaran Inkuiri Terbimbing Berbantuan Multimedia Interaktif Terhadap Berpikir Kritis Siswa Kelas Xi Sma Negeri Di Bojonegoro. Jurnal Pendidikan - Teori, Penelitian, Dan Pengembangan, 1(8), 1529-1535. https://doi.org/10.17977/jp.v1i8.6635

Sidin, A., \& Khaeruddin. (2012). Evaluasi Pembelajaran (1st ed.). Badan Penerbit UNM Makassar.

Triyanti, M. (2015). Pengembangan Multimedia Interaktif pada Materi Sistem Saraf untuk Meningkatkan Motivasi dan Hasil Belajar Siswa SMA Kelas XI. Jurnal Bioedukatika, $3(2), \quad 9$. https://doi.org/10.26555/bioedukatika.v3i 2.4148 
Jurnal Teknologi Pendidikan, Vol. 14, No. 1, April 2021, e-ISSN: 2407-7437

Wulandari, E. (2017). Penerapan multimedia interaktif berbasis macromedia flash 8 terhadap keaktifan dan hasil belajar biologi materi sistem saraf manusia pada siswa kelas XI SMA PPMI Assalaam Sukoharjo tahun pelajaran 2016/2017. 